\section{Structure Removal in Complex Prefields}

Gereon Müller (Universität Leipzig)

FU Berlin, October 27, 2015

\section{Introduction}

Observation:

Normally, only one item may show up in before the finite verb in main clauses (the verbsecond property). However, in the complex prefield construction, two (or more) items can show up in the domain preceding the finite verb in $\mathrm{C}$.

(1) Complex Prefields (widespread in sport broadcasts):

a. [DP Den Fahrer ] [pP zur Dopingkontrolle ] begleitete ein Chaperon the rider $_{a c c}$ to the doping test accompanied a chaperon nom $_{\text {. }}$

b. [DP Fast alles ] [PP im Sitzen ] bewältigte Joaquim Rodgriguez auf almost everything $_{a c c}$ seated managed Joaquim Rodgriguez on dem Weg zum Gipfe the way to the peak

c. [PP Mit dem Hauptfeld ] [PP ins Ziel ] kamen auch Fernando Escartin und with the peloton into the finish came also Fernando Escartin and Aitor Garmendia

Aitor Garmendia

d. [PP Mit ihm ] [PP in der Spitzengruppe ] fuhren Martin Elmiger (IAM), Bryan with him in the first group rode Martin Elmiger Bryan Nauleau (Europcar) und Serge Pauwels (MTN-Qhubeka)

Nauleau and Serge Pauwels

Two competing analyses:

- Prefields can be truly complex under certain circumstances. There are two (or more) separate constituents in the prefield in (1), as a consequence of an option of multiple fronting (cf. Lötscher (1985), Speyer (2008)): (2).

- Prefield complexity is only apparent. There is a single constituent in the prefield in (1), viz., a fronted VP with an empty head: (3). This empty head may be a trace resulting from prior head movement (cf. Müller (1998)), or it may be a separate empty head that does not (directly) participate in a displacement configuration (cf. Fanselow (1992), Müller, St. (2005); Müller, St. (2015)).
Multiple vs. single constituents

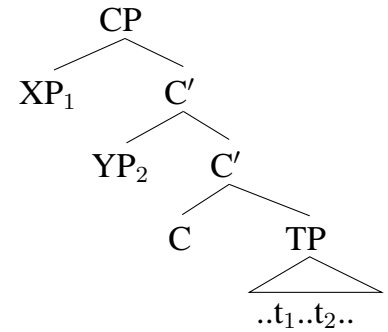

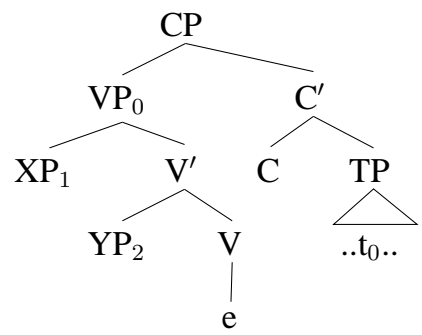

Claims:

- There is evidence both for single constituency and for multiple constituency in complex prefields in German.

- There is evidence for a derivational minimalist approach to conflicting representations in terms of structure removal, which can apply to both phrases and heads.

- Structure removal resolves the paradox: Complex prefield constructions result from (a) fronting of a VP with an empty head, followed by (b) removal of the VP shell.

\section{Conflicting Representations for Complex Prefields}

2.1. Evidence for Single Constituency

Note:

Most of the recent literature on complex prefields seems to adopt a single constituency (VP fronting) approach.

\subsubsection{Clause-Mate Condition}

Observation I (Fanselow (1992)):

The two items in a complex prefield must be clause-mates. This follows if it's a single VP constituent that undergoes the movement, but not if two items can move separately.

(4) A clause-mate condition as an argument for VP fronting

a. $\left[{ }_{\mathrm{CP}}\left[\mathrm{VP}_{0}\right.\right.$ Fahrern $\left._{1} \mathrm{EPO}_{2}\right] \quad\left[\mathrm{C}^{\prime}\right.$ sollte man besser nicht $\mathrm{t}_{0}$ geben $]$ riders $_{d a t}$ erythropoietin $_{a c c}$ should one better not give

b. *[CP Fahrern ${ }_{1} \mathrm{EPO}_{2} \quad\left[\mathrm{C}^{\prime}\right.$ sollte man besser nicht $\mathrm{t}_{1}$ nachsagen $[\mathrm{CP}$ riders $_{d a t}$ erythropoietin $_{a c c}$ should one $_{n o m}$ better not say about dass sie $\quad \mathrm{t}_{2}$ genommen haben $\left.]\right]$

that they nom $_{\text {taken }}$ have

2.1.2. Order Restrictions

Observation II (Müller, St. (2005); Müller, St. (2015), based on Susan Olsen (p.c.)):

The ordering restrictions among multiple items in complex prefields are identical to those in the middle field. This follows if the prefield constituent $i s$ the middle field constituent. 
(5) Unmarked order as an argument for VP fronting

a. (i) [CP Fahrern $\mathrm{EPO}_{2} \quad\left[\mathrm{C}^{\prime}\right.$ sollte man besser nicht geben ]] riders $_{d a t}$ erythropoietin $_{a c c}$ should one better not give

(ii) ? $\left[\mathrm{CP}_{\mathrm{CPO}} \mathrm{EPahrern}_{1}\left[\mathrm{C}^{\prime}\right.\right.$ sollte man besser nicht geben $\left.]\right]$ erythropoietin $_{a c c}$ riders $_{d a t}$ should one better not give

(iii) dass man Fahrern $\mathrm{Epo}_{2} \quad$ gegeben hat that one nom $_{\text {riders }}$ dat $_{\text {erythropoietin }}$ acc given has

(iv) ?dass man $\quad \mathrm{Epo}_{2} \quad$ Fahrern $_{1}$ gegeben hat that one nom $_{\text {erythropoietin }}$ acc riders $_{d a t}$ given has

b. (i) $\left[\mathrm{DP}_{1}\right.$ Den Fahrer $]\left[\mathrm{PP}_{2}\right.$ zur Dopingkontrolle $]$ begleitete ein the rider $_{a c c}$ to the doping test accompanied a

Chaperon

chaperon $_{\text {nom }}$

(ii) ?* $\left[\mathrm{PP}_{2}\right.$ Zur Dopingkontrolle $]\left[\mathrm{DP}_{1}\right.$ den Fahrer $]$ begleitete ein to the doping test the rider $_{a c c}$ accompanied a

Chaperon

chaperon $_{\text {nom }}$

(iii) dass ein Chaperon $\quad\left[\mathrm{DP}_{1}\right.$ den Fahrer $]\left[\mathrm{PP}_{2}\right.$ zur Dopingkontrolle $]$ that a chaperon ${ }_{n o m}$ the rider $_{a c c}$ to the doping test

begleitet hat accompanied has

(iv) ?*dass ein Chaperon $\quad\left[\mathrm{PP}_{2}\right.$ zur Dopingkontrolle ] [ ${ }_{\mathrm{DP}_{1}}$ den Fahrer ] that a chaperon ${ }_{n o m}$ to the doping test the rider $_{a c c}$

begleitet hat accompanied has

\subsubsection{Massive Prefield Placement}

Observation III (Fanselow (1992), Müller, St. (2005); Müller, St. (2015)):

More than two items may show up in a complex prefield; this may create theory-internal problems for the multiple fronting approach.

(6) More than two items as a possible argument for VP fronting:

$\left[\mathrm{PP}_{1} \mathrm{Im}\right.$ April $]\left[\mathrm{DP}_{2}\right.$ jede Woche $]\left[\mathrm{DP}_{3}\right.$ den Fahrern $]\left[\mathrm{DP}_{4}\right.$ ein EPO-Paket $]$
in april

hätte er lieber nicht schicken sollen

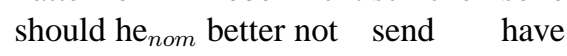

\subsection{Evidence for Multiple Constituency}

However:

There is also a lot of evidence for multiple constituency, some of which does not seem to have been noted so far.

\subsubsection{Freezing Effects}

Freezing (Ross (1967), Wexler \& Culicover (1980)):

Moved items are islands for further extraction. Possible analysis: Movement of some item always ends up in a specifier position, and subsequent extraction from that item will then violate the Condition on Extraction Domain (Huang (1982), Chomsky (1986)).)

Observation IV:

Extraction from an item in a complex prefield exhibits a freezing effect: An item in this position does not permit extraction even though it may do so in situ. This suggests that the item does not occupy a base position.

(7) Extraction in complex prefields 1:

a. [CP Dem Team [PP zum Erfolg ] [ $\mathrm{C}^{\prime}$ gratulierte Bernard Hinault ]] the team dat to the success congratulated Bernard Hinault ${ }_{\text {nom }}$

b. *[C ${ }_{\mathrm{CP}} \mathrm{Da}_{1}$ dem Team [ $\left.\mathrm{PP}_{1} \mathrm{zu}\right]\left[\mathrm{C}^{\prime}\right.$ gratulierte Bernard Hinault ]] there the team dat $_{\text {to }}$ to congratulated Bernard Hinault ${ }_{\text {nom }}$

c. $\left[{ }_{\mathrm{CP}} \mathrm{Da}_{1}\right.$ dem Team [ $\left.{ }_{\mathrm{PP}} \mathrm{t}_{1} \mathrm{zu}\right]$ gratulierte [ $\mathrm{C}^{\prime}$ hat Bernard Hinault $\left.]\right]$ there the team ${ }_{d a t}$ to congratulated has Bernard Hinault ${ }_{\text {nom }}$

d. [ $\left[\mathrm{CP}^{\mathrm{Da}} \mathrm{Da}_{1}\left[\mathrm{C}^{\prime}\right.\right.$ gratulierte Bernard Hinault dem Team [ $\left.\left.\mathrm{PP}_{1} \mathrm{zu}\right]\right]$ there congratulated Bernard Hinault $t_{n o m}$ the team ${ }_{d a t}$ to

e. dass Bernard Hinault da $\mathrm{da}_{1}$ dem Team $\quad\left[\mathrm{PP}_{1} \mathrm{t}_{1} \mathrm{zu}\right]$ gratulierte

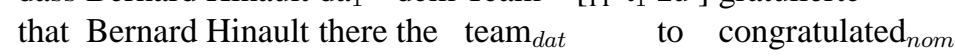

(8) Extraction in complex prefields 2:

a. [ $\quad$ СP Zum letzten Mal [Pp mit Funk ] [C' wurde das Rennen "Rund um die for the last time with radios was the race "Rund um die Braunkohle" ausgetragen ]]

Braunkohle" held

b. *[CP $\mathrm{Ca}_{1}$ zum letzten Mal [ $\mathrm{PP}_{1} \mathrm{t}_{1}$ mit $]\left[\mathrm{C}^{\prime}\right.$ wurde das Rennen "Rund um die there for the last time with was the race "Rund um die Braunkohle" ausgetragen ]] Braunkohle" held

c. $\left[\mathrm{CP}_{\mathrm{CP}} \mathrm{Da}_{1}\right.$ zum letzten Mal [PP $\mathrm{t}_{1}$ mit ] ausgetragen [ $\mathrm{C}^{\prime}$ wurde das Rennen there for the last time with held was the race

"Rund um die Braunkohle" ]]

"Rund um die Braunkohle"

d. $\mathrm{C}_{\mathrm{CP}} \mathrm{Da}_{1}\left[\mathrm{C}^{\prime}\right.$ wurde das Rennen "Rund um die Braunkohle" zum letzten Mal there was the race "Rund um die Braunkohle" for the last time [PP $\mathrm{t}_{1}$ mit ] ausgetragen ]] with held

e. dass das Rennen "Rund um die Braunkohle" da $a_{1}$ zum letzten Mal [pp $t_{1}$ that the race "Rund um die Braunkohle" there for the last time 
mit ]] ausgetragen wurde

with held was

(9) Extraction in complex prefields 3:

a. [CP Seinen Sprintern [DP einen Tipp dafür ] [ $\mathrm{C}^{\prime}$ hat der sportliche his sprinters $_{d a t}$ a hint ${ }_{a c c}$ there-for has the team Leiter von Rabobank gegeben ]] manager $_{a c c}$ of Rabobank given

b. *[CP $\mathrm{Da}_{1}$ seinen Sprintern [DP einen Tipp [ ${ }_{\mathrm{PP}} \mathrm{t}_{1}$ für $]$ [ [ $\mathrm{C}^{\prime}$ hat der sportliche there his sprinters $_{d a t}$ a hint acc $_{\text {for }}$ has the team

Leiter von Rabobank gegeben ]]

manager $_{\text {nom }}$ of Rabobank given

c. ${ }_{\mathrm{CP}} \mathrm{Da}_{1}$ seinen Sprintern [DP einen Tipp [ ${ }_{\mathrm{PP}} \mathrm{t}_{1}$ für $\left.]\right]$ gegeben [ $\mathrm{C}^{\prime}$ hat der there his sprinters $_{d a t}$ a hint ${ }_{a c c}$ for given has the sportliche Leiter von Rabobank ]]

team manager $_{\text {nom }}$ of Rabobank

d. $\left[{ }_{\mathrm{CP}} \mathrm{Da}_{1}\left[_{\mathrm{C}^{\prime}}\right.\right.$ hat der sportliche Leiter von Rabobank seinen there has the team manager nom $_{\text {of Rabobank his }}$ Sprintern [DP einen Tipp [PP $\mathrm{t}_{1}$ für ] gegeben ]] sprinters $_{d a t} \quad$ a hint $_{a c c}$ for given

e. dass der sportliche Leiter von Rabobank da $\mathrm{a}_{1}$ seinen Sprintern [DP that the team manager ${ }_{n o m}$ of Rabobank there his sprinters $_{d a t}$ einen Tipp [Pp $t_{1}$ für ] gegeben hat

a hint hacc $_{\text {for given has }}$

2.2.2. Barss' Generalization Effects

Barss's generalization (Barss (1986), Sauerland \& Elbourne (2002), Bhatt \& Dayal (2007), Neeleman \& van de Koot (2010), Heck \& Assmann (2014)):

A quantified item $\gamma$ contained in a moved XP $\alpha$ cannot take scope, via reconstruction, over a moved item $\beta$ base-generated in $\alpha$ that c-commands $\alpha$ 's trace and is c-commanded by $\alpha$.

\section{Observation $V$ :}

Unlike standard VP/vP frontings, complex prefields do not trigger Barss' generalization effects. This suggests that there is no VP present in the latter case.

(10) Barss' generalization as an argument for multiple constituents 1

a. [DP Jeden Fahrer ] begleitet ein Chaperon zur Dopingkontrolle every rider $_{a c c}$ accompanies a chaperon $_{n o m}$ to the doping test

$(\forall>\exists, \exists>\forall)$

b. [vp Jeden Fahrer zur Dopingkontrolle begleitet ] hat ein Chaperon every rider $_{a c c}$ to the doping test accompanied has a chaperon ${ }_{n o m}$ $(* \forall>\exists, \exists>\forall)$ c. [DP Jeden Fahrer] [pP zur Dopingkontrolle ] begleitet ein Chaperon every rider ${ }_{a c c}$ to the doping test accompanies a chaperon ${ }_{n o m}$

$$
(\forall>\exists, \exists>\forall)
$$

(11) Barss' generalization as an argument for multiple constituents 2

a. Drei Bidons gab der Soigneur zwei Fahrern in der Verpflegungszone three bidons $_{a c c}$ gave the soigneur $_{\text {nom }}$ two riders $_{d a t}$ in the feed zone

b. Drei Bidons in der Verpflegungszone gegeben hat der Soigneur zwei three bidons ${ }_{a c c}$ in the feed zone given has the soigneur $r_{n o m}$ two

Fahrern

riders $_{d a t}$

$(* 3>2,2>3)$

c. Drei Bidons in der Verpflegungszone gab der Soigneur zwei Fahrern

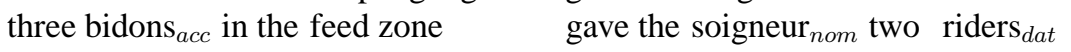

$(3>2,2>3)$

2.2.3. Bound Variable Pronouns

Weak Crossover constraint (cf. Heim \& Kratzer (1998); Kiss (2005) for the reverse formulation):

Pronouns that are interpreted as bound variables must be bound in syntactic output representations.

\section{Observation VI:}

Binding of pronouns interpreted as variables is much better with items in complex prefields than with items included in fronted VPs. This suggests that complex prefields do not involve fronted VPs.

(12) Bound variable pronouns as an argument for multiple constituents:

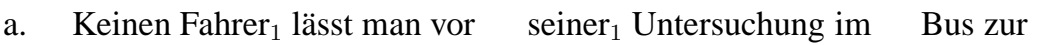
no rider $_{a c c}$ lets one before his examination in the bus to the Dopingkontrolle doping test

b. ??Keinen Fahrer $_{1}$ zur Dopingkontrolle gelassen hat man vor seiner $_{1}$ no rider $_{a c c}$ to the doping test let has one before his Untersuchung im Bus examination in the bus

c. Keinen Fahrer ${ }_{1}$ zur Dopingkontrolle lässt man vor seiner $_{1}$ no rider $_{a c c}$ to the doping test lets one before his

Untersuchung im Bus examination in the bus

d. ?*Keinen Fahrer ${ }_{1}$ zur Dopingkontrolle lassen würde $\operatorname{sein}_{1}$ Soigneur unter no rider $_{a c c}$ to the doping test let would his soigneur $_{n o m}$ under 
diesen Umständen

these circumstances

e. Keinen Fahrer ${ }_{1}$ zur Dopingkontrolle lässt $\operatorname{sein}_{1}$ Soigneur unter diesen no rider $_{a c c}$ to the doping test lets his soigner $_{n o m}$ under these

Umständen

circumstances

\subsection{Negative Polarity Items}

Negative polarity licensing (simplified):

A negative polarity item must be c-commanded by its antecedent.

Observation VII:

A fronted VP blocks such c-command (to some extent), complex prefields do not.

(13) Negative polarity licensing:

a. Keinen Berg hat auch nur irgendein französischer Fahrer im Sitzen bewältigt no hill has also only some French rider seated managed

b. *Im Sitzen hat auch nur irgendein französischer Fahrer keinen Berg bewältigt seated has also only some French rider no hill managed

c. Keinen Berg im Sitzen hat auch nur irgendein französischer Fahrer bewältig no hill seated has also only some French rider managed

d. ??Keinen Berg im Sitzen bewältigt hat auch nur irgendein französischer Fahrer no hill seated managed has also only some French rider

\subsection{Left Dislocation}

Observation VIII (Müller, St. (2005); Müller, St. (2015), based on Marga Reis (p.c.)):

The pronoun associated with a left-dislocated item typically targets the rightmost item in a complex prefield, and not a VP. This suggests that there is no VP present.

(14) Left dislocation as an argument for multiple constituents:

a. Zum dritten Mal die Flandernrundfahrt, die gewann Fabian for the third time the Ronde van Vlaanderen ${ }_{f e m}$, PRON $_{f e m}$ won Fabian Cancellara 2014 Cancellara 2014

b. *Zum dritten Mal die Flandernrundfahrt, das gewann Fabian for the third time the Ronde van Vlaanderen ${ }_{f e m}$, PRON $_{\text {neut }}$ won Fabian

Cancellara 2014 Cancellara 2014

c. *Zum dritten Mal die Flandernrundfahrt gewonnen, die hat for the third time the Ronde van Vlaanderen ${ }_{f e m}$ won, $\quad$ PRON $_{f e m}$ has Fabian Cancellara 2014 Fabian Cancellara 2014 d. Zum dritten Mal die Flandernrundfahrt gewonnen, das hat for the third time the Ronde van Vlaanderen ${ }_{f e m}$ won, $\quad$ PRON $_{n e u t}$ has Fabian Cancellara 2014

Fabian Cancellara 2014

\subsection{Extraposition to $V P$}

Observation IX (Müller, St. (2005); Müller, St. (2015), based on Tibor Kiss (p.c.)):

If the fronted item in complex prefields is a VP, there is no a priori reason why it cannot be targetted by extraposition to VP. The fact that this is not possible provides an argument for separate multiple fronting, and against a VP analysis.

(15) Extraposition to VP:

a. Den Wertungssiegern ihren Preis überreicht, die noch anwesend waren, the classification winners their price given who still present were hat Abraham Olano bei der Siegerehrung in Bilbao has Abraham Olano at the ceremony in Bilbao

b. *Den Wertungssiegern ihren Preis, die noch anwesend waren, hat the classification winners their price who still present were has Abraham Olano bei der Siegerehrung in Bilbao überreicht Abraham Olano at the ceremony in Bilbao given

Interim conclusion:

There is conflicting evidence as to what the structure of complex prefields in German looks like: Observations I-III suggest that there is a (headless) fronted VP structure, and observations IV-IX suggest that there truly is a multiple fronting structure.

Claim:

The two conflicting structures can be reconciled by adopting the principled approach to reanalysis phenomena sketched in Müller (2015b). This derivational, minimalist approach relies on a new concept of structure removal.

\section{Structure Removal}

Proposal:

Syntactic derivations employ two elementary operations modifying representations: In addition to an operation that builds structure - Merge (Chomsky (2001; 2008; 2013)) -, there is a complementary operation that removes structure: Remove.

\section{Conflicting representations:}

1. There is substantial evidence for conflicting representations in syntactic derivations.

2. The standard means to account for this is displacement: If some item $\alpha$ shows properties associated both with position $\mathrm{P}$ and position $\mathrm{Q}$, then this is due to the fact that $\alpha$ has moved from $\mathrm{Q}$ to $\mathrm{P}$. 
3. However, there are many cases of conflicting representations that do not lend themselves to analyses in terms of displacement.

4. These latter cases can be straightforwardly derived by structure removal.

\section{Observation}

If Remove exists as the mirror image of Merge, it is expected to show similar properties and obey identical constraints.

Assumptions about Merge:

(i) Merge is feature-driven. It is triggered by designated $[\bullet \mathrm{F} \bullet]$ features, which are ordered on lexical items (Svenonius (1994), Collins (2002), Adger (2003), Lechner (2004), Kobele (2006), Sternefeld (2006), Pesetsky \& Torrego (2006), Heck \& Müller (2007), Müller (2014), Abels (2012), Stabler (2013), Georgi (2014))

(ii) Merge may apply to heads (incl. head movement in cases of internal Merge) or phrases (incl. XP movement in cases of internal Merge): $\left[\bullet \mathrm{F}_{0} \bullet\right],\left[\bullet \mathrm{F}_{2} \bullet\right] .(0=\min , 2=\max$.)

(iii) Merge obeys the Strict Cycle Condition in (16) (Chomsky (1973; 1995; 2001; 2008); also cf. the Extension Condition and the No Tampering Condition).

(iv) Merge can be external or internal.

(16) Strict Cycle Condition (SCC):

Within the current XP $\alpha$, a syntactic operation may not exclusively target some item $\delta$ in the domain of another XP $\beta$ if $\beta$ is in the domain of $\alpha$.

(17) Domain (Chomsky (1995)):

The domain of a head X is the set of nodes dominated by XP that are distinct from and do not contain $\mathrm{X}$.

Note:

See Safir $(2010 ; 2015)$ for a similar concept (called Peak Novelty Condition in the more recent paper).

\section{Assumptions about Remove:}

(i) Remove is feature-driven. It is triggered by designated $[-\mathrm{F}-]$ features, which are ordered on lexical items.

(ii) Remove may apply to heads or phrases: $\left[-\mathrm{F}_{0}-\right],\left[-\mathrm{F}_{2}-\right]$.

(iii) Remove obeys the Strict Cycle Condition.

(iv) Remove can be external or internal.
(18) Remove and phrases: complements

a. $\operatorname{Merge}\left(\mathrm{X}_{\left[\bullet \mathrm{Y}_{\bullet}\right] \succ\left[-\mathrm{Y}_{2}-\right]}, \mathrm{YP}\right)$;

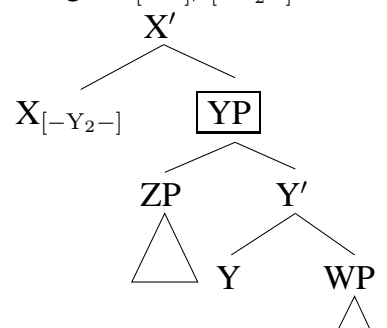

b. $\operatorname{Remove}\left(\mathrm{X}_{\left[-\mathrm{Y}_{2}-\right]}, \mathrm{YP}\right)$ :

Note:

$\mathrm{ZP}$, WP cannot be removed by $\mathrm{X}$ because of the Strict Cycle Condition.

(19) Remove and phrases: specifiers

a. $\operatorname{Merge}\left(\mathrm{X}_{[\bullet \mathrm{Y} \bullet] \succ\left[-\mathrm{Y}_{2-},\right.}, \mathrm{YP}\right)$ :

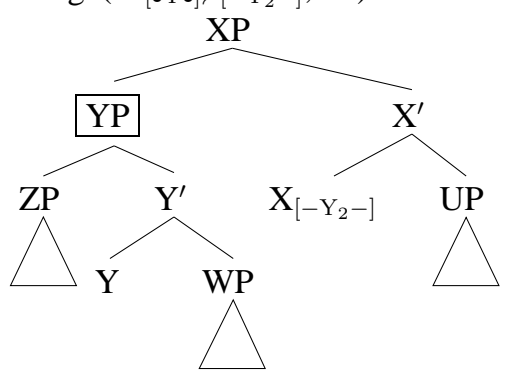

b. $\operatorname{Remove}\left(\mathrm{X}_{\left[-\mathrm{Y}_{2}-\right]}, \mathrm{YP}\right)$ :

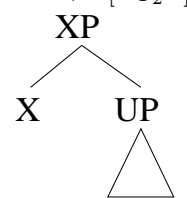

Note:

Again, ZP \& WP cannot be removed by $\mathrm{X}$ because of the Strict Cycle Condition. In principle,

$\mathrm{X}$ might also remove UP in this configuration after YP has been merged. To avoid this outcome, the Strict Cycle Condition could be strengthened (from phrases to projections). Alternatively, such a derivation might be permitted (also cf. Richards (2001) on tucking in with internal Merge). 
(20) Remove and heads: complements

a. $\operatorname{Merge}\left(\mathrm{X}_{[\bullet \mathrm{Y} \bullet] \succ\left[-\mathrm{Y}_{0}-\right]}, \mathrm{YP}\right)$ :

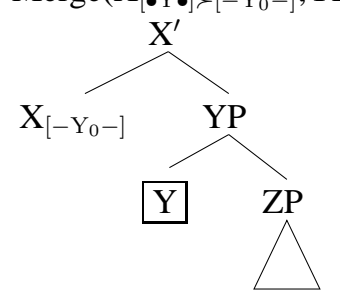

b. $\operatorname{Remove}\left(\mathrm{X}_{\left[-\mathrm{Y}_{0}-\right]}, \mathrm{Y}\right)$ :

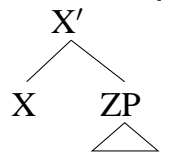

Since $\left[-\mathrm{F}_{0}-\right]$ removes the head, it takes away the highest projection, and only this. More deeply embedded material (like ZP) is attached to the head responsible for removal and replaces the original item (YP): This works exactly like tree pruning (see Ross (1967)). If there are two or more items in YP (e.g., ZP, WP), they reassemble in their original structural and linear order in the XP domain.

(21) Remove and heads: specifiers

a. $\quad \operatorname{Merge}\left(\mathrm{X}_{[\bullet \mathrm{Y} \bullet] \succ\left[-\mathrm{Y}_{0}-\right]}^{\prime}, \mathrm{YP}\right)$ :

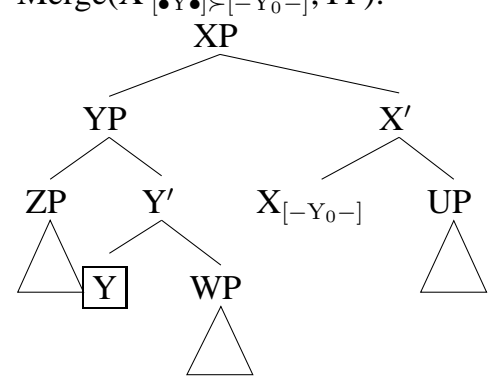

b. $\operatorname{Remove}\left(\mathrm{X}_{\left[-\mathrm{Y}_{0}-\right]}, \mathrm{Y}\right)$ :

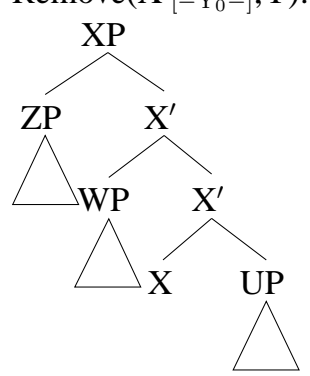

Short life cycle effects:

1. Some other operation $\Gamma$ can be interspersed between $\operatorname{Merge}(\mathrm{X}, \mathrm{YP})$ and Remove $(\mathrm{X}, \mathrm{Y}(\mathrm{P}))$.

2. However, due to the Strict Cycle Condition, a YP removed by [-F-] is predicted to have a short life cycle (unless it undergoes movement; see below): It is only accessible for other operations for a small part of the derivation.

3. Given incremental, bottom-up derivations, this implies that YP is accessible from below (downward accessibility) and inaccessible from above (upward inaccessibility): Remove counter-bleeds $\Gamma$ but bleeds subsequent operations (see Chomsky (1951), Kiparsky (1973)).

4. There is empirical evidence for short life cycle effects of this type.

5. Alternative accounts can only derive these kinds of effects on a case-by-case basis, as conspiracies because they cannot acknowledge, and model, a systematic pattern.

\section{Passive and Restructuring}

\subsection{Structure Removal in Passives: Phrases}

\section{Observation:}

There is evidence both for (Baker, Johnson \& Roberts (1989), Sternefeld (1995), Collins (2005)) and against (Chomsky (1981), Müller, St. (2007), Kiparsky (2013), Bruening (2013), Schäfer (2012), Alexiadou \& Doron (2013), and Alexiadou, Anagnastopoulou \& Schäfer (2015)) the syntactic presence of an external argument DP $\left(\mathrm{DP}_{e x t}\right)$ in German passive constructions.

(22) Conflicting representations - downward control vs. binding from above:

a. Das Schiff wurde $\mathrm{DP}_{\text {ext }}$ versenkt $\left[\mathrm{CP} \mathrm{PRO}_{1}\right.$ um die Versicherung zu the ship was sunk in order the insurance to kassieren ] ] collect

b. *Kein Student 1 glaubt [CP dass $\mathrm{PP}_{\text {ext }_{1}}$ gut gearbeitet wird] no student believes that well worked is

(23) Accessibility Generalization:

$\mathrm{DP}_{e x t}$ in passive constructions is accessible from below and inaccessible from above.

A new approach based on structure removal (Müller (2015b)):

Passive $=\left[-\mathrm{D}_{2}-\right]$ on $\mathrm{v}$ (plus subsequent case probe removal). 
(24) Control in passive derivations: $(22-a)$

a. $\operatorname{Merge}(v, V P)$

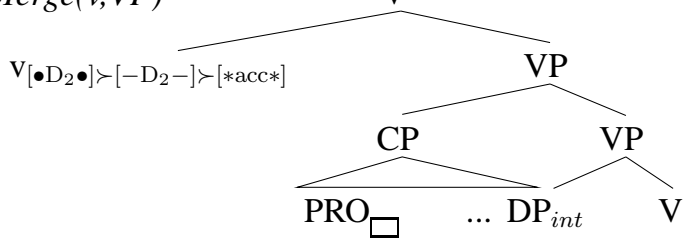

b. Control by $D P_{\text {ext }}: \operatorname{Merge}\left(D P_{\text {ext }}, v^{\prime}\right)$

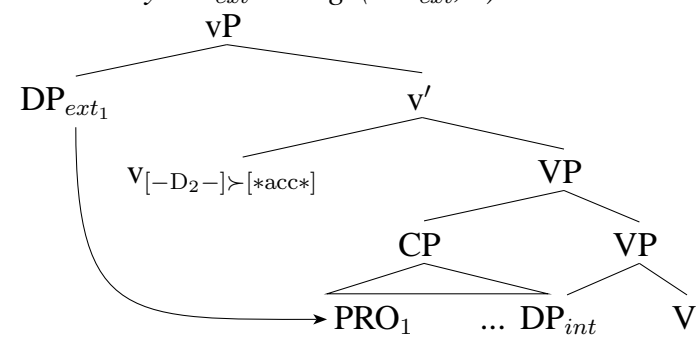

c. Counter-Bleeding of control by $D P_{\text {ext }}: \operatorname{Remove}\left(D P_{\text {ext }}, v^{\prime}\right)$

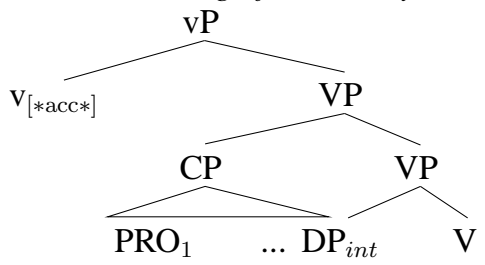

d. Case probe removal

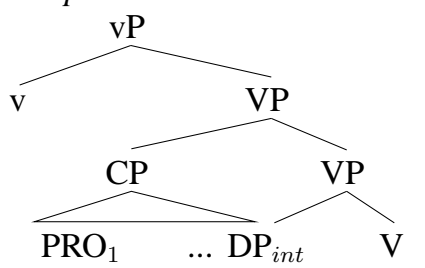

Note:

Remove would bleed control (because it removes the context in which control can apply) but comes too late to actually do so - control has already applied. Thus, opaque rule interaction results: counter-bleeding. The output representation is opaque because it is not clear how control can have applied successfully - there is no controller left at this point.
(25) Bound variable interpretation in passive derivations: (22-b)

a. $\operatorname{Merge}\left(D P_{\text {ext }}, v^{\prime}\right)$

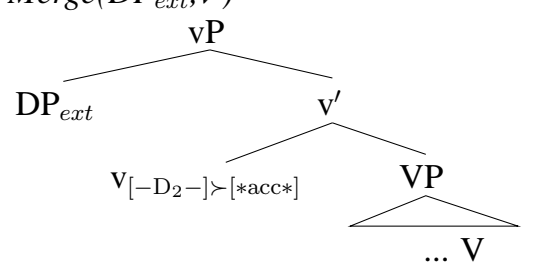

b. $\operatorname{Remove}\left(D P_{\text {ext }}, v^{\prime}\right)$

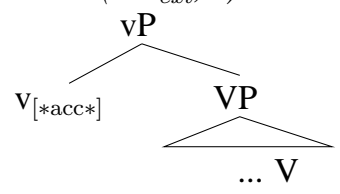

c. Case probe removal

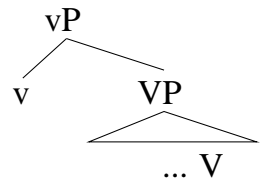

d. $\quad$...

e. Bleeding of binding of embedded $D P_{\text {ext }}$ : $\operatorname{Merge}\left(D P_{\text {ext }}, v^{\prime}\right)$ in the matrix clause

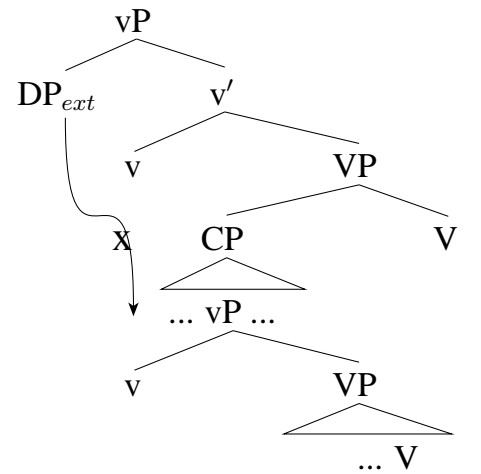

4.2. Structure Removal in Restructuring: Heads

Observation:

There is evidence both for biclausality (Sternefeld (1990)) and for monoclausality (Haider (1993; 2010), Kiss (1995), Wurmbrand (2001)) in German restructuring constructions.

(26) Conflicting representations: long-distance scrambling $v s$. binding from above:

a. (i) Der Oberförster ${ }_{1}$ hat $\mathrm{ihm}_{2} \quad\left(\mathrm{PRO}_{1}\right) \operatorname{sich}_{1}$ zu waschen versprochen the head forester has him dat REFL to wash promised

(ii) *Der Oberförster ${ }_{1}$ hat $\mathrm{ihm}_{2} \quad\left(\mathrm{PRO}_{1}\right) \operatorname{sich}_{2} \mathrm{zu}$ waschen versprochen the head forester has him dat REFL to wash promised 
(iii) Der Oberförster ${ }_{1}$ hat ihm $_{2} \quad \operatorname{sich}_{1 / 2}$ im $\quad$ Spiegel gezeigt the head forester has him dat REFL in the mirror shown

A new approach based on structure removal (Müller (2015b)):

- Restructuring verbs uniformly embed CPs, but they have Remove features that subsequently peel off CP, TP, ... (i.e., $\left[-\mathrm{C}_{0}-\right],\left[-\mathrm{T}_{0}-\right]$ ).

- Different kinds of restructuring infinitives may thus have different sizes, depending on the amount of structure that is successively removed by the matrix verb (Fanselow (1991), Wurmbrand (2001)).

- Operations that require the presence of $\mathrm{CP}(\mathrm{TP}, \ldots)$ are checked before structure removal (they are counter-bled and counter-fed by structure removal): Principle A in (26-a).

- operations that argue for monoclausality apply afterwards (bleeding, feeding): Scrambling in (26-b).

\section{Resolving the Paradox}

\subsection{Structure Removal in Complex Prefields}

Note:

Movement of XP may feed structure removal applying to XP or X, in line with the Strict Cycle Condtition in (16). (See Murphy (2014).)

\section{Proposal:}

In complex prefield constructions, remnant VP fronting (triggered by $\left[\bullet \mathrm{V}_{2} \bullet\right]$ on $\mathrm{C}$ ) feeds removal of the VP shell (triggered by $\left[-\mathrm{V}_{0}-\right]$ on $\mathrm{C}$ ).

(27) [DP Den Fahrer ] [pp zur Dopingkontrolle ] begleitete ein Chaperon the rider $_{a c c}$ to the doping test accompanied a chaperon ${ }_{n o m}$

(Note: In (28), e is the trace of moved lexical V; V may be in C or in a TP-right-peripheral position.)
(28)

Deriving complex prefields

a. Pre-movement structure:

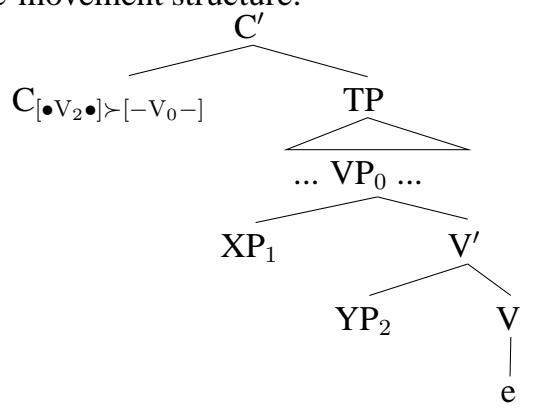

b. VP fronting:

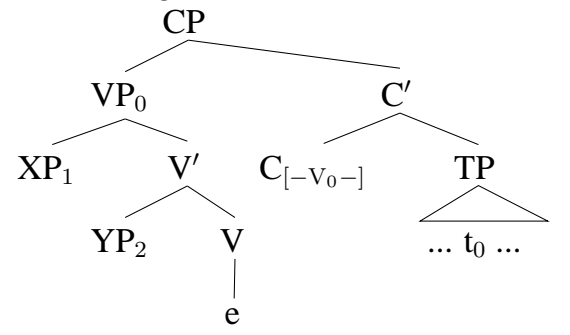

c. Structure removal:

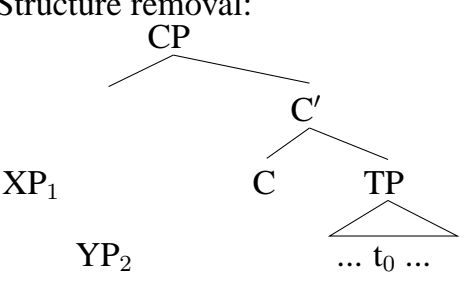

d. Reassociation:

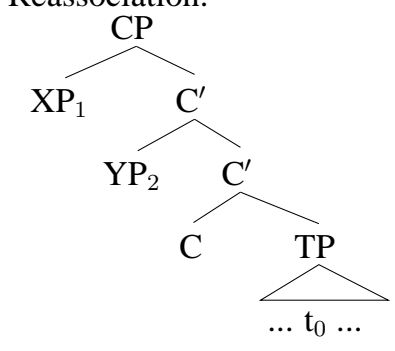

Note:

Movement of an item that is eventually targetted by structure removal can extend its life cycle somewhat. However, downward accessibility/upward unaccessibility of the item is predicted as before. 


\subsection{Deriving the Generalizations}

Note:

Evidence for a single VP constituent involves earlier (lower) stages of the derivation; evidence for multiple constituents involves later (higher) stages of the derivation.

I: Clause-mate condition $\rightarrow$ VP

Root $\mathrm{C}$ has only one structure-building feature in German; so only a single constituent (like VP) can move to the prefield.

II: Order restrictions $\rightarrow$ VP

Order restrictions are identical in VP and in the prefield because the item is identical: The only way for VP-internal material to undergo reordering (by scrambling etc.) is when VP is still in situ. (Given that root $\mathrm{C}$ has only one structure-building feature, and given that this is discharged by attracting a VP, the new specifiers it attains as a consequence of structure removal cannot subsequently undergo movement anymore.)

\section{III: Multiple Prefield Placement $\rightarrow$ VP}

VP can have arbitrarily many constituents (given $\mathrm{V}^{\prime}$ recursion).

\section{$I V:$ Freezing $\rightarrow X P, Y P$}

The evidence follows if the locality constraint responsible for deriving Freezing is not derivational but applies to output representations. The reason is that after structure removal, $\mathrm{YP}_{2}$ in (29) occupies a (derived) specifier position that is representationally indistinguishable from a position occupied as a consequence of movement (or other specifier positions which block extraction, for that matter). (However, the freezing effect also follows in a derivational approach under the assumptions about buffers made in Müller (2015a).)

(29) Freezing configuration:

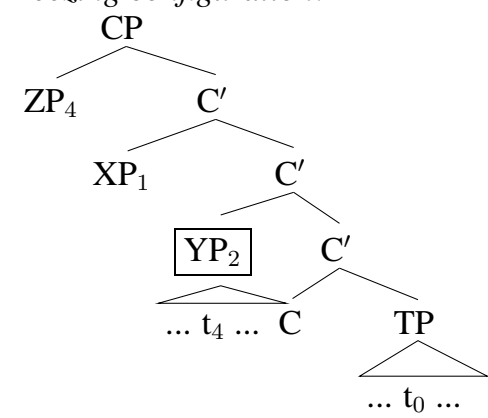

$V$ : Barss' generalization $\rightarrow X P, Y P$

Relative scope is an LF-related phenomenon that is determined on the basis of output representations, i.e., after structure removal. Hence, at the relevant stage, there is no VP anymore that might prevent a prefield item from taking scope over a middle-field internal item

VI: Bound variable pronouns $\rightarrow X P, Y P$

Variable binding is an LF-related phenomenon that is determined on the basis of output representations, i.e., after structure removal. C-command of the bound variable pronoun is impossible before VP removal and becomes possible afterwards.

VII: Negative polarity items $\rightarrow X P, Y P$

Negative polarity licensing is an LF-related phenomenon that is determined on the basis of output representations, i.e., after structure removal. C-command of the negative polarity item is impossible before VP removal and becomes possible afterwards.

VIII: Left Disclocation $\rightarrow X P, Y P$

Pronominal resumption is output-oriented.

$I X:$ Extraposition $\rightarrow X P, Y P$

If extraposition applies derivationally in the syntax, the non-availability of extraposition to VP is a priori unexpected (unless one can ensure that it can only take place after structure removal). If extraposition is a PF operation (Truckenbrodt (1994)), the effect follows without further ado.

(Alternative (Kiss (2005)): An extraposed relative clause must be in a higher position than the noun it modifies; after reassociation, this is impossible.)

\section{Outlook}

\section{Question 1:}

Can the approach be extended to complex prefield constructions with focus particles?

Answer:

Possibly yes; there might again be evidence for conflicting representations (cf. Jacobs (1983), Büring \& Hartmann (2001), Sternefeld (2006); Bayer (1996; 2015), Reis (2005), Meyer \& Sauerland (2009) for different points of view).

(30) a. Nur seine Mutter liebt jeder only his mother $_{a c c}$ loves everyone ${ }_{n o m}$

b. Einer nur hat die Polizisten angegriffen one $_{n o m}$ only has the policemen ${ }_{a c c}$ attacked

Question 2:

Can the approach to structure removal be maintained in declarative syntactic theories?

Answer:

As such, transferring the approach might be straightforward in LFG, much less so in HPSG. However, transferring structure removal to declarative analyses will not directly capture short 
life cycle effects, and will not directly derive the upward/downward accessibility asymmetry.

Question 3:

It seems that structure removal by $\mathrm{C}$ is only possible \& obligatory if the head of VP is empty. How can this be derived?

Answers:

(a) Optional $\left[-\mathrm{V}_{2}-\right]$ features on Cs plus recoverability; but this does not by itself result in obligatoriness in the relevant contexts.

(b) Last resort: $\mathrm{C}$ can have $\left[-\mathrm{V}_{2}-\right]$ features only if this is the only possibility to accomodate information-structural requirements demanding two separate constituents in the prefield.

Question 4:

Why are complex prefields often perceived as marked and require ideal informationstructural conditions (Bildhauer \& Cook (2010), Müller, St. (2015))?

Answer (speculative):

It seems that reanalysis phenomena (now conceived of as structural removal) are typically deep structure phenomena; feeding of structural removal by movement may qualify as a technically legitimate but marked option.

\section{References}

Abels, Klaus (2012): Phases. An Essay on Cyclicity in Syntax. Vol. 543 of Linguistische Arbeiten, De Gruyter, Berlin.

Adger, David (2003): Core Syntax. Oxford University Press, Oxford, New York.

Alexiadou, Artemis \& Edit Doron (2013): The Syntactic Construction of Two Non-Active Voices: Passive and Middle, Journal of Linguistics 48, 1-34.

Alexiadou, Artemis, Elena Anagnastopoulou \& Florian Schäfer (2015): External Arguments in Transitivity Alternations. Oxford University Press, Oxford.

Baker, Mark, Kyle Johnson \& Ian Roberts (1989): Passive Arguments Raised, Linguistic Inquiry 20, 219-251.

Barss, Andrew (1986): Chains and Anaphoric Dependence. Ph.d. thesis, MIT, Cambridge, Mass.

Bayer, Josef (1996): Directionality and Logical Form. On the Scope of Focussing Particles and Wh-in-situ. Kluwer, Dordrecht.

Bayer, Josef (2015): Criterial Freezing and the Syntax of Particles. Ms., Universität Konstanz.

Bhatt, Rajesh \& Veneeta Dayal (2007): Rightward Scrambling as Rightward Remnant Movement, Linguistic Inquiry 38, 287-301.

Bildhauer, Felix \& Philippa Cook (2010): German Multiple Fronting and Expected Topichood. In: S. Müller, ed., Proceedings of the 17th International Confer-ence on HeadDriven Phrase Structure Grammar. CSLI Publications, Stanford, CA, pp. 68-79.

Bruening, Benjamin (2013): By-Phrases in Passives and Nominals, Syntax 16, 1-41.

Büring, Daniel \& Katharina Hartmann (2001): The Syntax and Semantics of Focus-Sensitive Particles in German, Natural Language and Linguistic Theory 19, 229-281.

Chomsky, Noam (1951): Morphophonemics of Modern Hebrew. Master's thesis, University of Pennsylvania.

Chomsky, Noam (1973): Conditions on Transformations. In: S. Anderson \& P. Kiparsky, eds., A Festschrift for Morris Halle. Academic Press, New York, pp. 232-286.

Chomsky, Noam (1981): Lectures on Government and Binding. Foris, Dordrecht.

Chomsky, Noam (1986): Barriers. MIT Press, Cambridge, Mass.

Chomsky, Noam (1995): The Minimalist Program. MIT Press, Cambridge, Mass.

Chomsky, Noam (2001): Derivation by Phase. In: M. Kenstowicz, ed., Ken Hale. A Life in Language. MIT Press, Cambridge, Mass., pp. 1-52.

Chomsky, Noam (2008): On Phases. In: R. Freidin, C. Otero \& M. L. Zubizarreta, eds., Foundational Issues in Linguistic Theory. MIT Press, Cambridge, Mass., pp. 133-166.

Chomsky, Noam (2013): Problems of Projection, Lingua 130, 33-49.

Collins, Chris (2002): Eliminating Labels. In: S. D. Epstein \& T. D. Seely, eds., Derivation and Explanation in the Minimalist Program. Blackwell, Oxford, pp. 42-64.

Collins, Chris (2005): A Smuggling Approach to the Passive in English, Syntax 8, 81-120. Fanselow, Gisbert (1991): Minimale Syntax. Habilitation thesis, Universität Passau.

Fanselow, Gisbert (1992): The Return of the Base Generators. Ms., Universität Passau.

Georgi, Doreen (2014): Opaque Interactions of Merge and Agree. PhD thesis, Universität 
Leipzig.

Haider, Hubert (1993): Deutsche Syntax - generativ. Narr, Tübingen.

Haider, Hubert (2010): The Syntax of German. Cambridge University Press, Cambridge.

Heck, Fabian \& Anke Assmann (2014): Barss' Generalization and the Strict Cycle at LF. In:

A. Assmann, S. Bank, D. Georgi, T. Klein, P. Weisser \& E. Zimmermann, eds., Topics at Infl. Linguistische ArbeitsBerichte, Universität Leipzig, Institut für Linguistik, pp. 527560.

Heck, Fabian \& Gereon Müller (2007): Extremely Local Optimization. In: E. Brainbridge \& B. Agbayani, eds., Proceedings of the 26th WECOL. California State University, Fresno, pp. 170-183.

Heim, Irene \& Angelika Kratzer (1998): Semantics in Generative Grammar. Blackwell, Oxford.

Huang, Cheng-Teh James (1982): Logical Relations in Chinese and the Theory of Grammar. $\mathrm{PhD}$ thesis, MIT, Cambridge, Mass.

Jacobs, Joachim (1983): Fokus und Skalen. Niemeyer, Tübingen.

Kiparsky, Paul (1973): Abstractness, Opacity and Global Rules. In: O. Fujimura, ed., Three Dimensions in Linguistic Theory. TEC, Tokyo, pp. 57-86.

Kiparsky, Paul (2013): Towards a Null Theory of the Passive, Lingua 125, 7-33.

Kiss, Tibor (1995): Infinite Komplementation. Niemeyer, Tübingen.

Kiss, Tibor (2005): Semantic Constraints on Relative Clause Extraposition, Natural Language and Linguistic Theory 23, 281-334.

Kobele, Greg (2006): Generating Copies. PhD thesis, UCLA, Los Angeles.

Lechner, Winfried (2004): Extending and Reducing the MLC. In: A. Stepanov, G. Fanselow \& R. Vogel, eds., Minimality Effects in Syntax. Mouton de Gruyter, Berlin, pp. 205-240.

Lötscher, Andreas (1985): Syntaktische Bedingungen der Topikalisierung, Deutsche Sprache 13, 207-229.

Meyer, Marie-Christine \& Uli Sauerland (2009): A Pragmatic Constraint on Ambiguity Detection: A Rejoinder to Büring and Hartmann and to Reis, Natural Language and Linguistic Theory 27, 139-150.

Müller, Gereon (1998): Incomplete Category Fronting. Kluwer, Dordrecht.

Müller, Gereon (2014): Syntactic Buffers. Linguistische ArbeitsBerichte 91, Universität Leipzig.

Müller, Gereon (2015a): Freezing by Buffers. Talk, Workshop on Freezing, Universität Tübingen, 3-4 July 2015.

Müller, Gereon (2015b): Structure Removal. A New Approach to Conflicting Representations. Lecture Notes, Universität Leipzig.

Müller, Stefan (2005): Zur Analyse der scheinbar mehrfachen Vorfeldbesetzung, Linguistische Berichte 203, 297-330.

Müller, Stefan (2007): Head-Driven Phrase Structure Grammar: Eine Einführung. Stauffenburg, Tübingen, chapter 17: Passiv.

Müller, Stefan (2015): German Clause Structure: An Analysis with Special Consideration of So-Called Multiple Frontings. Empirically Oriented Theoretical Morphology and Syntax, Language Science Press, Berlin. With Contributions by Felix Bildhauer and Philippa
Cook.

Murphy, Andrew (2014): Stacked Passives in Turkish. In: A. Assmann, S. Bank, D. Georgi, T. Klein, P. Weisser \& E. Zimmermann, eds., Topics at Infl. Linguistische ArbeitsBerichte, Universität Leipzig, Institut für Linguistik, pp. 277-317.

Neeleman, Ad \& Hans van de Koot (2010): A Local Encoding of Syntactic Dependencies and its Consequences for the Theory of Movement, Syntax 13, 331-372.

Pesetsky, David \& Esther Torrego (2006): Probes, Goals and Syntactic Categories. Ms., MIT. Lingbuzz/000321

Reis, Marga (2005): On the Syntax of So-Called Focus Particles in German, Natural Language and Linguistic Theory 23, 459-483.

Richards, Norvin (2001): Movement in Language. Oxford University Press, Oxford

Ross, John (1967): Constraints on Variables in Syntax. PhD thesis, MIT, Cambridge, Mass.

Safir, Ken (2010): Viable Syntax: Rethinking Minimalist Architecture, Biolinguistics 4, 35107.

Safir, Ken (2015): It's a Conspiracy! The A/A'-Distinction as an Epiphenomenon. Ms., Rutgers University.

Sauerland, Uli \& Paul Elbourne (2002): Total Reconstruction, PF Movement, and Derivational Order, Linguistic Inquiry 33, 283-319.

Schäfer, Florian (2012): The Passive of Reflexive Verbs and Its Implications for Theories of Binding and Case, Journal of Comparative Germanic Linguistics 15, 213-268.

Speyer, Augustin (2008): Doppelte Vorfeldbesetzung im heutigen Deutsch und im Frühneuhochdeutschen, Linguistische Berichte 216, 455-485.

Stabler, Edward (2013): Two Models of Minimalist, Incremental Syntactic Analysis, Topics in Cognitive Science 5, 611-633.

Sternefeld, Wolfgang (1990): Scrambling and Minimality. In: G. Grewendorf \& W. Sternefeld, eds., Scrambling and Barriers. Benjamins, Amsterdam, pp. 239-257.

Sternefeld, Wolfgang (1995): Voice Phrases and Their Specifiers. Ms., Universität Tübingen. (SfS-Report 05-95)

Sternefeld, Wolfgang (2006): Syntax. Stauffenburg, Tübingen. Two volumes.

Sternefeld, Wolfgang \& Sam Featherston (2003): The German Reciprocal Einander in Double Object Constructions. In: L. Gunkel, G. Müller \& G. Zifonun, eds., Arbeiten zur Reflexivierung. Niemeyer, Tübingen, pp. 239-265.

Svenonius, Peter (1994): C-Selection as Feature-Checking, Studia Linguistica 48, 133-155. Truckenbrodt, Hubert (1994): Towards a Prosodic Theory of Extraposition. Ms., MIT.

Wexler, Ken \& Peter Culicover (1980): Formal Principles of Language Acquisition. MIT Press, Cambridge, Mass.

Wurmbrand, Susanne (2001): Infinitives. Restructuring and Clause Structure. Mouton de Gruyter, Berlin. 